\title{
Nutritional and Organoleptic Quality of Tempe Now with the Addition of Natural Dyeing Ingredients
}

\author{
Damiati Damiati ${ }^{1, *}$ Made Suriani ${ }^{1}$ \\ ${ }^{1}$ Culinary Arts Vocational Education Study Program, Universitas Pendidikan Ganesha, Singaraja, Indonesia \\ *Corresponding author. Email: damiati@undiksha.ac.id
}

\begin{abstract}
This study aims to determine (1) the nutritional quality of tempe noodle products with the addition of natural dyes (moringa leaf extract, beetroot extract, and dragon fruit peel extract), (2) determine the quality of the organoleptic test (taste, color, and texture) on the product. tempe noodles with the addition of natural coloring agents (moringa leaf extract, beetroot extract, and dragon fruit skin extract). dragon fruit, at a very high protein content is the addition of natural coloring ingredients of beetroot extract, which is $27.36 \% \mathrm{wt}$. The organic tempe is favourable since it is made of natural coloring of dragon fruit extract, which preserve the taste and texture, while improving the color. All the natural coloring in organic tempe have nutritional quality (protein and fat), organoleptic quality.
\end{abstract}

Keywords: Natural dyes, Nutritional quality, Organoleptic quality.

\section{INTRODUCTION}

Indonesia is a country rich in biodiversity ranging from fruits and plants which has 77 local food ingredients that contain natural dyes that have the potential to be used as natural dyes in food processing. [1]. A food's color plays a significant role in increasing customer acceptance of a food ingredient. Dyes, both natural and synthetic, are commonly added to processed foods in order to enhance their color.

Food additives, especially food coloring, are used to enhance the color of food. The impact of food coloring chemicals on human health is not often considered. Some people use food coloring in safe and effective ways. Coloring food is safe, although there is a threshold for its use. Natural dye extracts have been widely used. Various colors be extracted from plants such as beetroot, dragon fruit, and many others. The use of natural dye extracts has drawbacks, such as the colour being less durable, impractical, and interfering with food taste and aroma.

Turmeric extract, used as a natural preservative in the production of taro noodles, can increase the yellow color of the noodles [2]. Furthermore, in a study published in the International Journal of Scientific Engineering and Science, 2020, Artiningsih used natural dyes derived from dragon fruit extract to impart red color. Moringa leaves, beets, dragon fruit peels, and carrots are examples of plants that can also be used as natural colors.
Moringa is a local plant native to Indonesia which is rich in chlorophyll [3] so it has potential as a green dye. In addition, chlorophyll functions as a disinfectant and antibiotic, even before the advent of synthetic drugs. Moringa leaves are food ingredients that contain phytosterols, with levels of B-Sitoserol $3644.44 \mathrm{~g} / \mathrm{g}$, Kampesterol 1261.27 g/g and Stigmasterol $8363.91 \mathrm{~g} / \mathrm{g}$ [4]. In its use, natural dyes are usually less durable so they will experience instability both in storage and in food processing. Moringa leaves can be used as extracts or flour is one solution to extend shelf life and so that it can be used more for product diversification [5]. Moringa tempe noodles are one product that may be substituted with Moringa leaf extract, and the usage of 25\% Moringa leaf extract produces nice color and edable [6].

Beetroot is a Beta vulgaris tuber, subspecies vulgaris conditiva. Beetroot is good for body since it contains vitamins and low-saturated fat. It is good for reducing inflammation and cholesterol. As a food color, it will produce purplish red color.

Beetroot extract can be used to make tempe noodles. Tempe noodles are a healthy alternative with a protein content of 27.3 grams [7]. As a result, tempe noodles are a wholesome and nutritious food ingredient that the community can accept. 


\section{LITERATURE REVIEW}

\subsection{Moringa Leaves}

Moringa leaves are food ingredients that contain phytosterols with levels of B-Sitosterol $3644.44 \mathrm{~g} / \mathrm{g}$, Kampesterol $1261.27 \mathrm{~g} / \mathrm{g}$ and Stigmasterol $8363.91 \mathrm{~g} / \mathrm{g}$ [4]. Phytosterols are sterols found in plants and have a structure similar to cholesterol [8]. Phytosterols are plant sterols that are used as ingredients for growth and reproductive hormones.

In addition, Moringa leaves are food ingredients that contain protein, -carotene, and complete amino acids which are very good for meeting other food ingredients that are lacking in protein substances. However, Moringa leaves are a vegetable food that is easily damaged, has a less favourable aroma. But now, Moringa leaves have begun to be sought after by the public because they are one of the functional foods. The dark green leaves contain chlorophyll or pigment that can be used as a food additive which is used for food colouring which also functions for metabolism, the immune system, detoxification, relieve inflammation, and balance the hormonal system [3].

Moringa leaves are not easily damaged and their use is more practical, they can be processed into flour by using the boiled blanching + baking soda method. The steps for making Moringa leaf flour are through 3 stages, namely (1), the stage of preparing the ingredients; (2), drying stage; and the curing stage. The ingredients used are Moringa leaves that are in full bloom (3-4 stems from the top of the leaf), clean water, baking soda. The tools used are stoves, pans, basins and filters. In addition to making Moringa leaf flour, extracts can also be made, namely by smoothing Moringa leaves, then taking the juice only. The steps for making it are Moringa leaves that have been washed and then blended without using water and filtered Moringa leaf extract or juice.

\subsection{Beetroot}

High in nutrients, beetroot helps deliver blood to the brain and is good for healthy cells. Red blood cells can treat anemia. Betaine, a natural colorant utilized in food products, is responsible for the red color of beets. Natural pigments include colors found in food as well as pigments created by heating or storing. The chlorophyll, gradually changes from yellow to red carotenoids as they ripen.

\subsection{Dragon Fruit Skin}

Dragon fruit is an exotic plant that is quite popular in the world, especially in Southeast Asia. In Indonesia at this time dragon fruit is cultivated and the results are imported abroad, and lately a lot of research on dragon fruit, because it is known that dragon fruit has many benefits. That dragon fruit has many benefits, both flesh and skin. Dragon fruit peel can be used in food production as a natural food colorant, because dragon fruit peel contains antioxidants, one of which is anthocyanins.

Based on clinical trials conducted by Artiningsih [9] showed that not only dragon fruit flesh has benefits and functions as antioxidants, but dragon fruit skin which is brightly colored and tends to be scaly is also known to contain active compounds such as pentacyclic trlepene and 3aal, where both These compounds are useful as blood vessel flexibility which can reduce the potential for blood vessel rupture.

\subsection{Tempe Noodles}

Food diversification is a community nutrition strategy. No single item provides total nutritional worth, thus each dietary part must complement the other. Consuming a variety of foods improves the nutritional value of new foods and current foods. Tempe is an Indonesian cuisine with a rich history. These meals are made by fermenting soybeans or other nuts with Rhizopus sp [10]. The fungus that grows on soybeans hydrolyzes complex substances like carbs, lipids, and proteins into simple molecules that the body can digest like glucose, fatty acids, and amino acids. and affect family dietary satisfaction Because tempe has many advantages over other food ingredients derived from soybeans such as tofu, such as decreased levels of nutrients in the form of phytic acid, and high NPU (Net Protein Utilization) [11], it is felt necessary to develop and promote it widely. Tempe also improves blood antioxidant capacity and lowers DNA damage in wistar rats exposed to UV radiation [11]. Also, tempe is a functional diet with high nutrients, particularly protein [13]. Tempe noodles are made by replacing up to $25 \%$ of the main ingredient in noodle products, wheat flour, with tempe flour. Tempe noodles are abundant in protein and carbs. The body needs protein to repair damaged cells and produce new ones, especially in children. Carbohydrates provide energy because they include glucose or other monosaccharides that provide energy when digested.

\section{METHOD}

This is an experimental study, with the goal of providing treatment with natural ingredient extract formulations as natural coloring agents in tempe noodle products. In order to gather data on the nutritional quality of the usage of natural dye extracts in tempe noodle products, the following measures must be taken:

(1) Making tempe noodle products with the addition of extracts of natural dyes (moringa leaf extract, beetroot extract, and dragon fruit peel extract). 
(2) Analyze the nutritional quality of tempe noodle products with the addition of extracts of natural dyes (moringa leaf extract, beetroot extract, and dragon fruit peel extract) which will be carried out at the BPOM Bali laboratory or at the agricultural faculty laboratory at Unud Denpasar Bali.

(3) Performing organoleptic test analysis (taste, color, and texture) on tempe noodle products with the addition of extracts of natural dyes

Data will be investigated in this study utilizing descriptive analytic techniques, which means that the data will be reviewed using a questionnaire that contains an organoleptic test for preferences or tastes that covers characteristics such as flavor, color, and texture. It is possible to score well on the preference test utilizing a hedonic scoring system that considers flavor, color, and texture.

\section{RESULT AND DISCUSSIONS}

\subsection{Tempe noodle products with the addition of extracts of natural coloring agents}

Some tempe noodle products have been made using additional ingredients in the form of food coloring. The natural food coloring materials used are Moringa leaf extract is shown in Figure 1, the noodle product is shown in Figure 2, the beetroot extract product is shown in Figure 3 and 4, and material used of dragon fruit peel extract as shown in Figure 5.

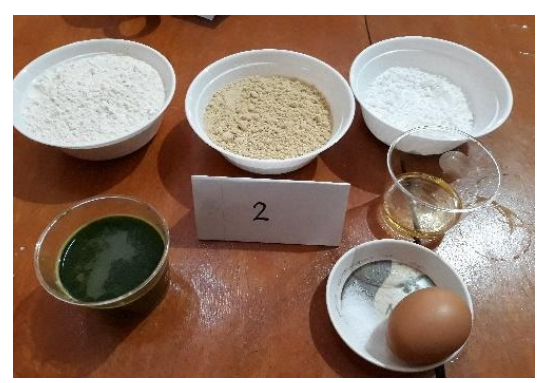

Figure 1 The natural food coloring materials used

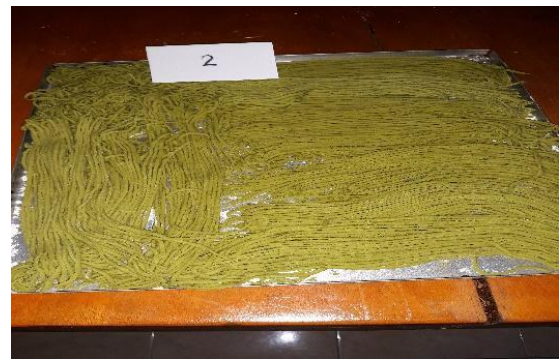

Figure 2 Moringa leaf extract tempe noodle products

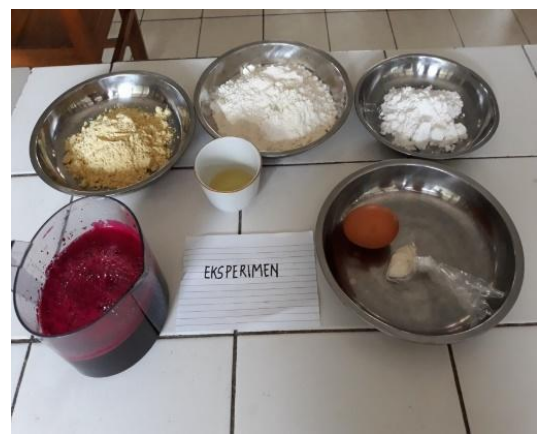

Figure 3 Material used of beetroot extract tempe noodles 


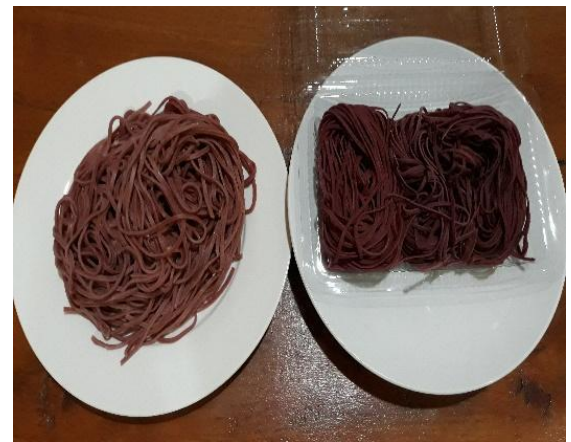

Figure 4 Products of beetroot extract tempe noodles

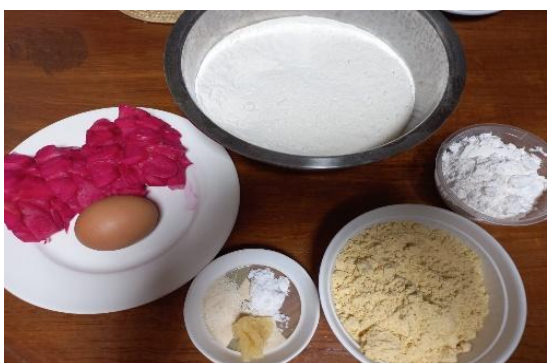

Figure 5 Material used of dragon fruit peel extract tempe noodle products

4.2. Analysis of the nutritional quality of tempe noodle products with the addition of extracts of natural dyes (moringa leaf extract, beetroot extract, and dragon fruit peel extract),

This nutritional analysis was carried out in the laboratory of the Faculty of Agriculture, Unud, and the results are shown on Table 1 .
4.3. Analysis of organoleptic tests (taste, color, and texture) on tempe noodle products with the addition of extracts of natural dyes (moringa leaf extract, beetroot extract, dragon fruit peel extract).

The organoleptic test was carried out using 25 people as panelists, namely PKK nutrition cadres and posyandu in Banyuasri sub-district with the following table 2.

Table 1. Nutritional Quality

\begin{tabular}{|l|l|l|l|l|l|}
\hline \multirow{2}{*}{ NO } & \multicolumn{2}{|c|}{ Natural Dyes } & \multicolumn{5}{c|}{ Nutritional Quality } \\
\cline { 3 - 6 } & & Water content & Ash Content & Protein Content \\
$(\%)$ & $\%$ Fat Content (\%bk) & \\
\hline 1 & Moringa Leaf Extract & 10,29 & 1,62 & 26,59 & 12,37 \\
\hline 2 & Bit Fruit Extract & 9,97 & 1,29 & 27,36 & 10,65 \\
\hline 3 & Dragon Fruit Peel Extract & 76,80 & 1.532 & 22,098 & 8,653 \\
\hline
\end{tabular}


Table 2. Organoleptic Test

\begin{tabular}{|l|l|l|l|l|}
\hline \multirow{2}{*}{ NO } & \multicolumn{2}{|c|}{ Natural Dyes } & \multicolumn{3}{c|}{ Organoleptic Test } \\
\cline { 3 - 5 } & & \multicolumn{1}{|c|}{ Color } & \multicolumn{1}{c|}{ Texte } & Vexture \\
\hline 1 & Moringa Leaf Extract & Very liked & Liked & Very liked \\
\hline 2 & Bit Fruit Extract & Very liked & Liked & Very liked \\
\hline 3 & Dragon Fruit Peel Extract & Very liked & Very liked & Very liked \\
\hline
\end{tabular}

\section{CONCLUSION}

The study shows that the use of natural dyes for coloring contains $27.36 \% \mathrm{ww}$, while the fat is $12.37 \%$ bk. The assessment of the by 25 panelist showed that the organoleptic quality of the tempe noodle is favourable. The use of natural colowing improve the nutritional quality of the tempe noodle.

The natural coloring ingredients of Moringa leaf extract and dragon fruit peel have a very good value, this is because Moringa leaves are rich in chlorophyll [3] so they have potential as green dyes. In addition, chlorophyll functions as a disinfectant and antibiotic, even before the advent of synthetic drugs, so the results of this study have illustrated that the moringa tempe noodle product is very good for consumption.

Meanwhile, dragon fruit peel can be used in food production as a natural food coloring, because dragon fruit skin contains antioxidants, one of which is anthocyanins. The taste and texture of the natural dye of dragon fruit extract has a value and the response from the panelists is very good.

\section{REFERENCES}

[1] Astuti.U.P., dkk. 2012. Laporan Akhir Tahun: Model Kawasan Rumah Pangan Lestari Provinsi Bengkulu TA 2012. Balai Pengkajian Teknologi Pertanian Bengkulu. Bengkulu.

[2] Ervika, dkk, 2019. The effect of yellow collor from turmeric on physical and Sensory properties of arengostrch-taro (Colocasia esculanta L) flour noodles. Indonesian Journal of Natural Pigments

[3] Limantara, L. 2007. Klorofil: Pigmen kehidupan. BioS, Vol. 1, No.1, hal. 2-10.

[4] T. Mutiara, "Uji Efek Pelancar ASI Tepung Daun Kelor (Moringa oleifera (Lamk)," 2011.

[5] T. Mutiara Titi, E.S.W. Estiasih, Effect lactagogue moringa leaves (Moringa oleifera Lam) powder in rats, J. Basic Appl. Sci. Res., 3 (2013), pp. 430-434
[6] Damiati. 2018. Pemanfaatan ekstak daun kelor sebagai bahan pewarna alami pada pembuatan produk mie tempe.

[7] Damiati, 2019. Potensi ekstrak buah bit (beetroot) sebagai bahan pewarna alami pada pembuatan produk mie tempe.

[8] Jansen Silalahi. 2006. Makanan Fungsional. Yogyakarta: Kanisius. h.118-24.

[9] Artiningsih Ayu Komang, 2020. Enveriomental Managemen and utilizing gragon fruit peel waste an natural food coloring. International Journal of Scientific Engeneering and Science.

[10] Astawan. 2009. Sehat dengan hidangan kacang dan biji-bijian.CetakanI :Penebar Swadaya, Jakarta.

[11] Maryam Siti. $2009 \quad$ Analisa kuantitatifkomponenbiaktif pada tempe yang difermentasi dengan menggunakan inokulum campuran rhizopusoligosporus dan rhizopusoryzae.

[12] Maryam Siti dan Damiati. 2016. Pengembangan mie sehat berbahan baku tepung tempe menjadi mie tempe.

[13] Winarti S. 2010. Makanan Fungsional, cetakan I; Grahallmu, Yogyakarta. 